\title{
An Analysis of Aggregate Market Liquidity: The Case of Amman Stock Exchange
}

\author{
Dima Waleed Hanna Alrabadi \\ Assistant Professor, Finance and Banking Sciences Department, \\ Faculty of Economics and Business Administration, Yarmouk University, P.O Box 566, Irbid 21163, Jordan
}

Tel: 96-22-721-1111 ext. 6856 E-mail: dhws2004@yahoo.co.uk

Received: November 16, 2011

Accepted: April 4, 2012

Published: May 1, 2012

doi:10.5539/ibr.v5n5p184

URL: http://dx.doi.org/10.5539/ibr.v5n5p184

\begin{abstract}
The purpose of this study is to analyze the behavior, the day-of-the-week regularities and the macroeconomic determinants of aggregate market liquidity of emerging stock markets through studying Amman Stock Exchange (ASE). The study investigates all the stocks traded in ASE over the period 2002-2010. Aggregate market liquidity is measured by several proxies, each reflecting a certain dimension. It is calculated as an average of individual stock liquidity proxies and as a sum of trading activity measures. Aggregate market liquidity shows a fluctuating pattern throughout the study period. It gets worse in the mid-week. Spread and depths show their maximum values on Mondays and Sundays, respectively. The trading activity reaches its minimum on Sunday and its maximum on Thursday. Major macroeconomic factors significantly affect aggregate market liquidity, though; aggregate market return and volatility exercise a larger effect. This study is the first to conduct a comprehensive analysis of aggregate market liquidity in an emerging stock market.
\end{abstract}

Keywords: Aggregate market liquidity, Day-of-the-week effect, Macroeconomic factors, Amman Stock Exchange, Time series analysis

\section{Introduction}

Liquidity is a very important feature of financial markets. It is a multi-dimensional phenomenon concerning the quickness and ease of trading without a significant price change. Early literature focused on individual stock liquidity and its effect on return. However, aggregate market liquidity has been the focus of researchers since the beginning of the last decade. Investors, business organizations, regulators, policy makers and others do concern about the behavior and determinants of aggregate market liquidity given its importance for the functioning of the stock exchanges and for the economy as a whole. This study constructs a comprehensive analysis of aggregate market liquidity in ASE, an emerging stock market, over the period 2002-2010. The analysis includes three main parts; the behavior, the day-of-the-week effect and the macroeconomic determinants.

Understanding the drivers and possible seasonality effects of market liquidity is without doubt vital. Some reasons could be mentioned. First, Liquidity is a core function of the market. Investors enter the market either supplying or demanding liquidity. Second, market liquidity is also an essential factor influencing both the aggregate market return and the individual stock return. Third, fluctuations of market liquidity could predict financial crises. A recent study for Naes et al. (2011) concerning the last global financial crises shows that liquidity in the stock market desiccating as a sign to the crisis in the real economy. To the best of the researcher's knowledge, understanding the behavior of aggregate market liquidity in emerging markets is still limited. This study inspects whether the characteristics, determinants and day-of-the-week regularities of aggregate market liquidity in an emerging market are comparable to developed ones.

Our findings can be summarized as follows: market liquidity shows a fluctuating pattern throughout the study period. In particular, it has moved upward from the beginning of the study period to 2005 and downward thereafter. We argue that there was no direct effect of the global financial crisis on the ASE given its local nature. However, the global financial crisis has indirectly affected the ASE through its effect on investors' psychologies and thus their willingness to invest. There are significant day-of-the-week regularities in market liquidity. Contrasting the US evidence of Chordia et al. (2001), market liquidity reaches its minimum in the middle of the week. Trading activity is significantly higher in Thursdays and lower in Sundays comparing to other days of the week. Jordanian Investors seem to avoid trading at the beginning of the week given the higher adverse selection costs. This is consistent with 
Foster and Viswanathan (1993) who found analogous results of the trading volume for NYSE. Spreads show their maximum values on Mondays while depths do so on Sundays. Gross Domestic Product (GDP), Money Supply (M2), Industrial Production (IP), Consumer Price Index (CPI), Unemployment rate (UNEMP), term spread (TERM) and quality spread (CREDIT) do significantly affect different proxies of liquidity. Nevertheless, aggregate market return and volatility appear to have the largest and most significant effects on aggregate market liquidity.

The remainder of the study is organized as follows. Section 2 reviews the related literature. Section 3 briefly introduces ASE. Section 4 describes our data. Section 5 presents the research methodology. Section 6 reports the empirical results and Section 7 concludes on the main findings.

\section{Literature Review}

Chordia et al. (2000) have shifted the focus of liquidity research from the individual stock level to the overall market level. Indeed, the authors introduced a new phenomenon called commonality in liquidity and defined it as the co movement between individual stock liquidity and market liquidity. The commonality is found to exist in developed markets (Huberman \& Halka, 2001; Hasbrouck \& Seppi, 2001; Giouvris, 2003) as well as in emerging markets (Brockman \& Chung, 2002; Sujoto et al., 2005; Qin, 2007). Launching this area of research, authors have moved toward analyzing aggregate market liquidity, (Chordia et al., 2001; Fujimoto, 2003) and investigating whether its variations affect stock returns (Jones, 2002; Amihud, 2002; Bekaert et al., 2003; Pastor and Stambaugh, 2003; Gibson \& Mougeot, 2004; Acharya \& Pedersen, 2005; Liu, 2006).

Our work is related to several parts of the finance literature. One important part is the regularities in stock market. Voluminous literature has document a day-of-the-week effect in stock returns. The effect typically happens when stock returns are negative on Monday or lower than the returns of the other days. On the other hand, Friday returns are highest among all other days. Cross (1973), French (1980), Gibbons and Hess (1981), Lakonishok and Levi (1982), Keim and Stambaugh (1984), Rogalski (1984), Harris (1986), Smirlock and Starks (1986), Lakonishok and Smidt (1988) and Mehdian and Perry (2001) are among others who find a day-of-the-week effect in the US stock market. The anomaly is found to exist in most developed and emerging stock markets all over the globe (Lyroudi et al., 2002; Paudyal \& Draper, 2002; Patev et al., 2004; Kenourgios \& Samitas, 2005; Dicle \& Hassan, 2007; Choudhary \& Choudhary, 2008; Dicle \& Levendis, 2010; Huang et al., 2010). Comparing with this huge research on the daily regularities of stock returns, very little is known about regularities in aggregate stock market liquidity.

Other related literature to this study is about the macroeconomic effects on stock market. Earlier research has focused on the effect of macroeconomic factors on stock returns. Chen et al. (1986) have started this line of research. They find that term structure, industrial production, risk premium, inflation, market return, consumption and oil prices significantly explain the returns in the US stock market. Following studies confirm the explanatory power of macroeconomic variables on stock returns, (Chen, 1991; Patelis, 1997; Thorbecke, 1997; Ferson \& Harvey, 1999; Mayasami \& Koh, 2000; Gan et al., 2006; Alzubi \& salameh, 2007; Cunsel \& Cukur, 2007; Gay, 2008; Tursoy et al., 2008; Mohammad et al., 2009; Pal \& Mittal, 2011). Parallel to these studies, some authors document a significant relationship between macroeconomic variables and stock market liquidity. Sen and Ghosh (2008) find that Index of Industrial Production, Consumer Price Index, Exchange Rate, Gold price and Money Supply have significant positive effects on the Indian Stock Market liquidity. Liquidity is measured by turnover rate and Amivest ratio. Lu and Glascock (2010) find that the pricing of liquidity can be partially explained by business cycles and the rate of growth in industrial production in the US stock markets. Naes et al. (2011) uncover a strong relation between stock market liquidity and the business cycle. Choi and cook (2005) report that liquidity shocks in the Japanese Stock Market are associated with some macroeconomic events. Soderberg (2008) investigates the macroeconomic variables' ability to forecast changes in monthly liquidity on the Scandinavian order-driven stock exchanges and reports weak evidence.

There is a direct link between our study and those of Chordia et al. (2001) and Fujomoto (2003). Chordia et al. (2001) examine the time varying characteristics and the determinants of aggregate market liquidity of NYSE over the period 1988-1998. They find that aggregate market spreads, depths and volume are highly volatile and their daily changes are serially correlated. Market return, market volatility, short term interest rate and term spread are significant explanatory variables for market liquidity. Moreover, a day-of-the-week effect is apparent. Fridays encompass lowest liquidity while Tuesdays are most liquid. Over the last four decades, Fujimoto (2003) investigates the macroeconomic sources of aggregate market liquidity in US markets as well. Their results can be summarized as follows. The supply-side inflation and monetary policy shocks are the main macroeconomic factors that explain the time varying behavior of aggregate market liquidity. Market liquidity increases significantly in return to negative inflation shocks and expansionary monetary policy shocks. In addition to the direct effect, the two macroeconomic factors indirectly affect market liquidity through their effect on market variables as return, volatility and turnover. 
However, the effect is time varying. Thus, it has lessened over the last two decades given that the economy has developed into more steadiness.

\section{Amman Stock Exchange}

ASE is an emerging stock market that has been established in 1976. It applies an automated order driven system. Investors cannot trade unless through brokers. The brokers trade on the system remotely (from their offices) or use trading screens located in the ASE head quarters. They trade on behalf of their customers and for their own inventory. Trading takes place in a continuous basis. Specifically, the brokers enter buy and sell orders into the trading system.

The system arranges orders according to price/time priority. In particular, bid prices are ordered in priority from highest to lowest, while ask prices are arranged from lowest to highest. Bid-ask spread is defined as the difference between the lowest ask price and the highest bid price. Depth is a function of the average number of shares available at the lowest ask and highest bid prices. Again, the system matches orders and executes them according the price/time priority. Trade size is not a priority in execution. The system keeps the traders anonymous until the order is executed. This order driven trading system has different provisions of liquidity providing from the dealership markets. Investors rather than dealers are the liquidity providers. There is no obligation for the investor to provide liquidity and thus no inventory risk exists. The investors face only information asymmetry risk. The market is free to enter or exit.

In addition to the trading system, one more issue is worthy to mention about the ASE, its key statistics. According to the statistics of 2010, ASE consists of 277 companies with a market capitalization of JD 21,858.2 millions. The market capitalization represents $122.7 \%$ of the GDP. The daily trading volume averages approximately JD 26.75 millions. The number of traded shares and the number of transactions per year are 6988.8 million and 1880.2 thousand, respectively. Finally, the number of trading days is 250 .

\section{Data}

The data set consists of daily closing trading data for all the stocks that are traded in ASE throughout the period 2002-2010, inclusive. For each stock, it includes the daily quantity and dinar trading volume, the opening and closing prices for the day, the highest and lowest prices during the day, the daily number of trades and the best quoted bid and ask prices and their corresponding quoted quantities. All the companies that are traded in any day are included with no any exception. This may enrich the analysis of aggregate market liquidity. Moreover, quarterly data of macroeconomic variables are obtained from the Central Bank of Jordan (CBJ). These variables are: GDP, M(2), IP, CPI, UNEMP, and the interest rate on Treasury bills, Treasury bond, and loans. Eight liquidity measures are employed, the absolute quoted bid-ask spread (SPR), the proportional quoted bid-ask spread (PSPR), the quoted quantity depth (DEP), the quoted dinar depth (DDEP), the Amihud's (2002) illiquidity ratio (AM), the number of trades (NO), the quantity trading volume (QTY) and the dinar trading volume (VOL). Obviously, the study uses a number of different measures in order to reflect the different dimensions of liquidity. SPR and PSPR reflect the cost dimension, DEP and DDEP indicate by definition the quantity dimension, QTY, VOL and NO are related to the trading activity aspect of liquidity and AM is a proxy for price impact. The calculations of these measures are shown in Table 1. Aggregate market values of SPR, PSPR, DEP, DDEP and AM in a certain day are calculated by averaging their values for all the stocks that are traded on that day. However, aggregate market values of QTY, VOL and NO are calculated by summing their values for all the stocks that are traded on a certain day.

\section{Methodology}

Three different methods are used in this study. Descriptive statistics and charts are used to describe the behavior of aggregate market liquidity throughout the study period. The day-of-the-week effect is investigated through estimating the following time series regression model which includes five dummy variables, one for each day of the week:

$L_{t}$ : is the aggregate market liquidity on day $t$.

$$
\begin{aligned}
& L_{t}=B_{1} D_{1 t}+B_{2} D_{2 t}+B_{3} D_{3 t}+B_{4} D_{4 t}+B_{5} D_{5 t}+\sum_{j=1}^{10} B_{j+5} \times L_{t-j}+e_{t} \\
& \text { arket liquidity on day } t \text {. }
\end{aligned}
$$

$D_{j t}$ : are dummy variables which take on the value 1 if the corresponding liquidity for day $t$ is a Sunday, Monday, Tuesday, Wednesday or Thursday, respectively and 0 otherwise.

The model is estimated without an intercept in order to avoid the dummy variable trap (for more information, see Gujarati, 2004). The OLS estimation of this model show significant ARCH effects. In other words, the variance of the residuals obtained from the estimation of the model is time-dependent. Consequently, GARCH $(1,1)$ model of Bollerslev (1986) is used in order to solve this problem. Moreover, ten days lags of the dependent variable are added 
as supplementary regressors so as to correct for the autocorrelation between residuals. A different liquidity proxy is used each time the model is estimated with the purpose of investigating the day-of-the-week regularities in the different dimensions of aggregate market liquidity.

The last part of the study examines the effect of macroeconomic variables on aggregate market liquidity through the OLS estimation of the following time series regression model:

$$
\begin{aligned}
& C L_{t}=B_{0}+B_{1} C G D P_{t}+B_{2} C M 2_{t}+B_{3} C C P I_{t}+B_{4} C I P_{t}+B_{5} \text { CTERM }_{t} \\
& +B_{6} \text { CREDIT }_{t}+B_{7} C U N E M P_{t}+B_{8} M T_{t}+B_{9} \text { VOT }_{t}+e_{t}
\end{aligned}
$$

Where

$C L_{t}:$ is the percentage change in aggregate market liquidity in quarter $t$

$C G D P_{t}$ : is the percentage change in Gross Domestic Product in quarter $t$

$C M 2_{t}$ : is the percentage change in Money Supply (2) in quarter $t$

$C C P I_{t}$ : is the percentage change in Consumer Price Index in quarter $t$

$C I P_{t}$ : is the percentage change in Industrial Production Index in quarter $t$

CTERM $_{t}$ : is the percentage change in Term Spread in quarter $t$

CCREDIT $_{t}$ : is the percentage change in Credit Spread in quarter $t$

CUNEMP $P_{t}$ : is the percentage change in Unemployment Rate in quarter $t$

$M K T_{t}$ : is the rate of return on stock market index

$V O T_{t}$ : is the aggregate market volatility measured by averaging the individual stocks' squared returns.

Literature suggests a long list of different variables in order to represent the economic conditions. This study uses the macroeconomic variables that have sufficient data available from the CBJ. Augmented Dickey-Fuller and Phillips-Perron unit root tests show a nonstationarity problem in the time series. Daily percentage changes rather than levels are used for the dependent and independent variables in order to avoid it. Market return and volatility are added as control variables in order to isolate their possible effects on aggregate market liquidity. Newey-West HAC Standard Errors and Covariance is used to account for heteroskedasticity and serial correlation in the obtained residuals. Regression is estimated on a quarterly basis because some macroeconomic variables such as credit term are only available on that basis. Other studies use longer periods of time to examine this issue, however, the unavailability of data has limited this study to a 9-year period. Yet, this does not affect the reliability of the regression results. According to the central limit theorem, 30 observations are enough to run an OLS regression. In our case, 36 observations are employed. Chow Break Point test is used to check for any structural changes in data.

A Vector Autoregression (VAR) is also estimated for equation (2) in order to explore any dynamics in the relationships. A lag length of 2 is employed and selected according to Akaike Information Criterion (AIC).

\section{Empirical Results}

\subsection{Descriptive Statistics}

Descriptive statistics of liquidity variables are reported in Table 2. All liquidity variables are highly volatile indicated by the high values of coefficient of variation. As an emerging market, these values are even higher than their comparable ones of NYSE documented by Chordia et al. (2001). Means and medians differ significantly demonstrating that none of these liquidity variables is normally distributed.

Figure 1 plots the AM; it has declined through 2002-2003, stabilized through 2004-2005, and showed an increase through 2006-2007. Over the first half of 2008, the AM has decreased. However, it has increased rapidly starting from the mid of 2008 to the end of 2010. Spread measures in Figure 2 show a similar trend to the AM. Figure 3 shows the depth measures, they display two main increases in 2005 and 2008. Trading volume measures in Figures 4 and 5 exhibit an opposite behavior to the AM. They have increased through 2002-2005, declined through 2006-2007. However, they reached their maximum in mid 2008 and then have declined thereafter to the end of the sample period. Overall, aggregate market liquidity has improved through 2002-2005 because of the technical and the legal developments of ASE. In 2006 and 2007 the trading volume decreased and the economy slow downed although of the establishment of a number of companies. Most exchanges in the world witnessed a hold up in 2006. The situation has improved in the first half of 2008. However, a significant brake happened in the mid of 2008. Liquidity has dried up swiftly through 2009-2010. The direct reason could be initiating an investment substitute. A large number of companies that trade in the global equity markets and FOREX were established. Most Jordanian 
investors direct their investments toward these companies. This, in turn, has pulled liquidity from the ASE. The global financial crises can be an indirect reason through its effect on the Jordanian investors' psychologies. Fears from the possible effects of the global financial crises on the Jordanian economy have limited their investments in ASE.

\subsection{Regularities of Liquidity}

Table 3 presents the regression results for the day-of-the-week regularities of aggregate market liquidity. AM shows significant coefficient on Wednesday. Thus, liquidity seems to be poorer in the middle of the week. Spread measures reach their maximum on Mondays. On the other hand, depth measures are highest on Sundays. Both coefficients are statistically significant. Trading activity measures show some how different results. QTY and VOL exhibit their greatest values on Thursday. They show negative coefficients on Sunday. NO has also a negative coefficient on Sunday. Different liquidity measures show different results. This may be due to the fact that each liquidity proxy reflects a specific aspect of liquidity.

Our results are dissimilar to those reported by Chordia et al. (2001) for NYSE. In particular, Chordia et al. (2001) document that aggregate market liquidity and trading activity are highest in mid-week, lowest on Fridays. The contradictory results may arise from the nature of ASE. As an emerging market, investors' psychologies do have a large effect on their trading behavior. They seem to be conservative to trade at the beginning of the week given the ambiguity surrounding stock prices. This is consistent with the information asymmetry paradigm (Bagehot, 1970; Copeland \& Galai, 1983; Glosten \& Milgrom, 1985) under which investors avoid trading when the adverse selection cost is high. The opposite happens on the last day of the week where all information is already revealed. Foster and Viswanathan (1993) found similar results with respect to trading volume in NYSE.

\subsection{Macroeconomic Sources of Aggregate Market Liquidity}

Table 4 displays the OLS regression results of the macroeconomic sources of aggregate market liquidity. The regression is estimated on quarterly basis (Daily percentage changes in aggregate market liquidity are transformed into quarterly basis). Percentage changes in IP, M2 and UNEMP significantly affect the percentage change in the aggregate market AM. The IP has a negative effect while the other two variables have positive effects. There is no statistically significant effect of macroeconomic variables on spread and depth measures. This is in some way consistent with Chordia's et al. (2001) results who find no significant effect of GDP and unemployment announcements on bid-ask spreads. One could explain that investors do not directly consider the macroeconomic conditions when they quote their bid-ask quantities and prices. Trading activity measures, on the other hand, are highly affected by macroeconomic variables. Most coefficients are statistically significant. The coefficients of percentage changes in GDP, UNEMP and CREDIT are negative. The adjusted R squared of the estimated regressions ranges from $26 \%$ when DEP proxies for liquidity to $78 \%$ when liquidity is measured by VOL. The analysis reveals one important outcome; that is, in all regressions the coefficients of aggregate MKT and VOT are the largest and the most significant among others. This exerts their vital explanatory power of aggregate market liquidity. Indeed, these market variables are more essential in explaining the aggregate market liquidity than the macroeconomic variables.

Table 5 reports the results of the Chow test based on 2006 as a break point. The test shows no significant structural changes in the relationship between macroeconomic indicators and most of liquidity and trading activity measures. Finally, Table 6 reveals some lagged effects of the variables examined on aggregate market liquidity indicating some temporal associations explored by the VAR.

\section{Conclusion}

This study analyses the behavior, regularities and macroeconomic determinants of aggregate market liquidity in ASE through the period 2002-2010. The Aggregate market liquidity showed an upward trend throughout 2002-2005. The main reason is what the market has witnessed of improvement on the technological and the legal levels. In 2006 and 2007 it has slowed down given the sluggish economy not only in Jordan but all over the world. The situation showed an improvement at the beginning of 2008 however a down trend has started from the mid of 2008 to the end of the sample period. The latter trend according to the author argument could be as a result of establishing companies that trade in the global equity markets and FOREX. Investing in such companies was a substitute to the investment in ASE for the Jordanian investor. One other explanation is the global financial crises which affect our investors' willingness to invest. Thus, it has directed the investor toward saving rather than taking the risk of investment, especially in financial assets.

Day-of-the-week effect is not only limited to the stock market return. It also characterizes its aggregate market liquidity. Liquidity worsens in the mid-week. Spread and depths show their maximum values on Mondays and 
Sundays, respectively. The trading activity illustrates its minimum on Sunday and reaches its maximum on Thursday.

Macroeconomic factors exert significant effects on aggregate market illiquidity ratio and trading activity measures, however, their effect is small if compared with the aggregate market return and volatility.

Our findings are important to market practitioners in ASE. Investors who enter the market to buy or sell will be concerned about when it is liquid. Regulators and policy makers will also be interested to know what determines the aggregate market liquidity. Finally, business organizations will choose their financing sources according to the required rates of return on their stocks which in a manner depends in a large extent on market liquidity.

\section{References}

Acharya, V., \& Pedersen, L. (2005). Asset pricing with liquidity risk. Journal of Financial Economics, 77(2), 375-410. http://dx.doi.org/10.1016/j.jfineco.2004.06.007

Alzubi, K., \& Salameh, H. (2007). Explaining the stock return via a macroeconomic multifactor model. Jordan Journal of Business Administration, 3(1), 106-120.

Amihud, Y. (2002). Illiquidity and stock returns: cross-section and time series effects. Journal of Financial Markets, 5(1), 31- 56. http://dx.doi.org/10.1016/S1386-4181(01)00024-6

Bagehot, W. (1971). The only game in town. Financial Analyst Journal, 27(2), 12-32. http://dx.doi.org/10.2469/faj.v27.n2.12

Bekaert, G., Harvey, C. R., \& Lundblad, C. (2003). Liquidity and expected returns: lessons from emerging markets. Retrieved from: www.ssrn.com

Bollerslev, T. (1986). Generalized autoregressive conditional heteroskedasticity. Journal of Econometrics, 31(3), 307-327. http://dx.doi.org/10.1016/0304-4076(86)90063-1

Brockman, P., \& Chung, D. Y. (2002). Commonality in liquidity: evidence from an order driven market structure. Journal of Financial Research, 25(4), 521-539. http://dx.doi.org/10.1111/1475-6803.00035

Chen, N. (1991). Financial investment opportunities and the macroeconomy. Journal of Finance, 46(2), 529-554. http://dx.doi.org/10.2307/2328835

Chen, N., Roll, R., \& Ross, S. A. (1986). Economic forces and the stock market. Journal of Business, 59(3), 383-403. http://dx.doi.org/10.1086/296344

Choi, W. G., \& Cook, D. (2005). Stock market liquidity and the macroeconomy: evidence from Japan. IMF Working paper.

Chordia, T., Roll, R., \& Subrahmanyam, A. (2000). Commonality in liquidity. Journal of Financial Economics, 56(1), 3- 28. http://dx.doi.org/10.1016/S0304-405X(99)00057-4

Chordia, T., Roll, R., \& Subrahmanyam, A. (2001). Market liquidity and trading activity. The Journal of Finance, 56(2), 501- 530. http://dx.doi.org/10.1111/0022-1082.00335

Choudhary, K., \& Choudhary, S. (2008). Day-of-the-week effect: further empirical investigation. Asia Pacific Business Review, 14(3), 1-6.

Copeland, T., \& Galai, D. (1983). Information effects and the bid-ask spread. Journal of Finance, 38(5), 1457-1469. http://dx.doi.org/10.2307/2327580

Cross, F. (1973). The behavior of stock price on Fridays and Mondays. Financial Analyst Journal, 29(6), 67-69. http://dx.doi.org/10.2469/faj.v29.n6.67

Cunsel, N., \& Cukur, S. (2007). The effects of macroeconomic factors on the London stock returns: a sectoral approach. International Research Journal of Finance and Economics, 10, 140-152.

Dicle, M. F., \& Hassan, M. K. (2007). Day-of-the-week effect in Istanbul Stock Exchange. Scientific Journal of Administrative Development, 5, 53-83.

Dicle, M. F., \& Levendis, J. (2010). Day-of-the-week effect revisited: international evidence. Retrieved from: www.ssrn.com.

Ferson, W. E., \& Harvey, C. R. (1999). Conditioning variables and the cross section of stock returns. Journal of Finance, 54(4), 1325-1360. http://dx.doi.org/10.1111/0022-1082.00148

Foster, F. D., \& Viswanathan, S. (1993). Variations in trading volume, return volatility, and trading costs: evidence on recent price formation models. Journal of Finance, 48(1), 187-211. http://dx.doi.org/10.2307/2328886 
French, K. (1980). Stock returns and the weekend effect. Journal of Financial Economics, 8(1), 55-70. http://dx.doi.org/10.1016/0304-405X(80)90021-5

Fujimoto, A. (2003). Macroeconomic sources of systematic liquidity. Working Paper, Yale University.

Gan, C., Lee, M., Yong, H. H. A., \& Zhang, J. (2006). Macroeconomic variables and stock market interaction: New Zealand evidence. International Management and Financial Innovation, 3(4), 89-101.

Gay, R. (2008). Effect of macroeconomic variables on stock market returns for four emerging economies: Brazil, Russia, India, And China. International Business and Economic Research Journal, 7(3), 1-8.

Gibbons, R. S., \& Hess, P. (1981). Day-of-the-week effects and asset returns. Journal of Business, 54(4), 579-96. http://dx.doi.org/10.1086/296147

Gibson, R., \& Mougeot, N. (2004). The pricing of systematic liquidity risk: empirical evidence from the US Stock Market. Journal of Banking and Finance, 28(1), 157-178. http://dx.doi.org/10.1016/S0378-4266(02)00402-8

Giouvris, E. (2003). Systematic liquidity and expected returns: evidence from the London Stock Exchange. Working Paper, University of Durham.

Glosten, L., \& Milgrom, P. (1985). Bid, ask and transaction prices in a specialist market with heterogeneously informed traders. Journal of Financial Economics, 14(1), 71-100. http://dx.doi.org/10.1016/0304-405X(85)90044-3

Gujarati Damodar, N. (2004). Basic econometrics (4th ed.). Boston, MA: McGraw-Hill.

Harris, L. (1986). A transaction data study of weekly and intradaily patterns in stock returns. Journal of Financial Economics, 16(1), 99-117. http://dx.doi.org/10.1016/0304-405X(86)90044-9

Hasbrouck, J., \& Seppi, D. (2001). Common factors in prices, order Flows, and liquidity. Journal of Financial Economics, 59(3), 383- 411. http://dx.doi.org/10.1016/S0304-405X(00)00091-X

Huang, Z., Hu, O., \& Liao, B. (2010). Short sale, stock liquidity, and the day-of-the-week effect: evidence from the Taiwan Stock Market. Review of Pacific Basin Financial Markets and Policies, 13(1), 71-90. http://dx.doi.org/10.1142/S0219091510001871

Huberman, G., \& Halka, D. (2001). Systematic liquidity. Journal of Financial Research, 24(2), 161-178.

Jones, C. M. (2002). A century of market liquidity and trading costs. Working Paper, Columbia University.

Keim, B. D., \& Stambaugh, R. F. (1984). A further investigation of the weekend effect in stock returns. Journal of Finance, 39(3), 819-840. http://dx.doi.org/10.2307/2327945

Kenourgios, D., \& Samitas, A. (2005). The day-of-the-week effect patterns on stock market return and volatility: evidence for the Athens Stock Exchange. Retrieved from: www.ssrn.com

Lakonishok, J., \& Levi, M. (1982). Week-end effects on stock returns: a note. Journal of Finance, 37(3), 883-89. http://dx.doi.org/10.2307/2327716

Lakonishok, J., \& Smidt, S. (1988). Are seasonal anomalies real? A ninety-year perspective. Review of Financial Studies, 1(4), 403-25. http://dx.doi.org/10.1093/rfs/1.4.403

Liu, W. (2006). A liquidity augmented capital asset pricing model. Journal of Financial Economics, 82(3), 631-671. http://dx.doi.org/10.1016/j.jfineco.2005.10.001

Lu, R., \& Glascock, J. (2010). Macroeconomic effects on stock liquidity. Working Paper, University of Cincinnati.

Lyroudi, K., Subeniotis, D., \& Komisopoulos, G. (2002). Market anomalies in the A.S.E: the day-of-the-week effect. Retrieved from: www.ssrn.com.

Mayasami, R. C., \& Koh, T. C. (2000). A vector error correction model of Singapore Stock Market. International Review of Economics and Finance, 9(1), 79-96. http://dx.doi.org/10.1016/S1059-0560(99)00042-8

Mehdian, S., \& Perry, M. (2001). The reversal of the Monday effect: new evidence from US equity markets. Journal of Business Finance and Accounting, 28(7\&8), 1043-1065. http://dx.doi.org/10.1111/1468-5957.00404

Mohammad, S. D., Hussain, A., \& Ali, A. (2009). Impact of macroeconomics variables on stock prices: empirical evidence in case of KSE (Karachi Stock Exchange). European Journal of Scientific Research, 38(1), 96-103.

Naes, R., Skjeltorp, J. A., \& Odegaard, B. A. (2011). Stock market liquidity and the business cycle. Journal of Finance, 66(1), 139-176.

Pal, K., \& Mittal, R. (2011). Impact of macroeconomic indicators on Indian capital markets. The Journal of Risk Finance, 12(2), 84-97. http://dx.doi.org/10.1108/15265941111112811 
Pastor, L., \& Stambaugh, R. (2003). Liquidity risk and expected stock returns. Journal of Political Economy, 111(3), 642-685. http://dx.doi.org/10.1086/374184

Patelis, A. D. (1997). Stock return predictability and the role of monetary policy. Journal of Finance, 52(5), 1951-1972. http://dx.doi.org/10.2307/2329470

Patev, P. G., Lyoudi, K., \& Kanaryan, N. K. (2004). The day-of-the-week effect in the central European transition stock markets. Retrieved from: www.ssrn.com.

Paudyal, K., \& Draper, P. (2002). Explaining Monday returns. Journal of Financial Research, 25(4), 507-520. http://dx.doi.org/10.1111/1475-6803.00034

Qin, Y. (2007). Liquidity and commonality in emerging markets. Working Paper, National University of Singapore.

Rogalski, R. (1984). New findings regarding day-of-the-week returns over trading and non-trading period. Journal of Finance, 39(5), 1603-14. http://dx.doi.org/10.2307/2327747

Sen, S. S., \& Ghosh, S. K. (2008). Association between stock market liquidity and some selected on Indian Stock Market macroeconomic variables: a case study. The IUP Journal of Financial Economics, 6(3), 53-73.

Smirlock, M., \& Starks, L. (1986). Day-of-the-week and intraday effects in stock returns. Journal of Financial Economics, 17(1), 197-210. http://dx.doi.org/10.1016/0304-405X(86)90011-5

Soderberg, J. (2008). Do macroeconomic variables forecast changes in liquidity? An out-of-sample study on the order-driven stock markets in Scandinavia, Retrieved from: www.ssrn.com.

Sujoto, C., Kalev, P., \& Fafft, W. (2005). An examination of commonality in liquidity: new evidence, long run effects and non-linearities. Working Paper, Monash University.

Thorbecke, W. (1997). On stock market returns and monetary policy. Journal of Finance, 52(2), 635-654. http://dx.doi.org/10.2307/2329493

Tursoy, T., Gunsel, N., \& Rjoub, H. (2008). Macroeconomic factors, the APT and the Istanbul Stock Market. International Research Journal of Finance and Economics, 22, 50-57.

Table 1. Liquidity measures

\begin{tabular}{|c|c|}
\hline $\begin{array}{l}\text { Absolute Quoted Bid-Ask } \\
\text { Spread (SPR) }\end{array}$ & $S P R_{i, t}=P_{i, t}^{A}-P_{i, t}^{B} \quad$ where: $P_{i, t}^{A}$ is ask price of stock $i$ at time $t \cdot P_{i, t}^{B}$ is bid price of stock $i$ at time $t$ \\
\hline $\begin{array}{l}\text { Proportional Quoted } \\
\text { Bid-Ask Spread (PSPR) }\end{array}$ & $P S P R_{i, t}=\frac{\left(P_{i, t}^{A}-P_{i, t}^{B}\right)}{\left(P_{i, t}^{A}+P_{i, t}^{B}\right) / 2}$ \\
\hline Quoted Depth (DEP) & $\begin{array}{l}D E P_{i, t}=\frac{Q_{i, t}^{A}+Q_{i, t}^{B}}{2} \text { where: } Q_{i, t}^{A} \text { is ask quoted quantity of stock } i \text { at time } t \cdot Q_{i, t}^{B} \text { is bid quoted quantity } \\
\text { of stock } i \text { at time } t\end{array}$ \\
\hline $\begin{array}{ll}\text { Quoted Dollar Depth } \\
\text { (DDEP) }\end{array}$ & $D D E P_{i, t}=\frac{Q_{i, t}^{A} * P_{i, t}^{A}+Q_{i, t}^{B} * P_{i, t}^{B}}{2}$ \\
\hline $\begin{array}{l}\text { Amihud's } \\
\text { Illiquidity Ratio (AM) }\end{array}$ & $\begin{array}{l}A M_{i, t}=\frac{\left|R_{i, t}\right|}{V O L_{i, t}} \text { where: } V O L_{i, t} \text { is the dollar volume of stock } i \text { at time } t . R_{i, t} \text { is the return on stock } i \text { at } \\
\text { time } t\end{array}$ \\
\hline
\end{tabular}


Table 2. Descriptive statistics

\begin{tabular}{lcccccccc}
\hline & AM & SPR & PSPR & DEP & DDEP & QTY & NO & VOL \\
\hline Mean & 0.000 & 0.129 & 0.085 & 9051 & 16713 & 13919100 & 9175 & 36644923 \\
Median & 0.000 & 0.108 & 0.064 & 6640 & 11058 & 12553618 & 8906 & 28903610 \\
Maximum & 0.001 & 2.885 & 1.367 & 63427 & 269074 & 99395426 & 29883 & $447 \times 10^{6}$ \\
Minimum & 0.000 & -2.086 & -0.826 & 1175 & 1455 & 282593 & 453 & 451315 \\
Std. Dev. & 0.000 & 0.291 & 0.162 & 7220 & 19456 & 10901278 & 5600 & 33461187 \\
Skewness & 4.167 & 1.271 & 1.738 & 2.079 & 4.085 & 1.569 & 0.509 & 2.091 \\
Kurtosis & 28.206 & 19.547 & 13.278 & 9.401 & 30.284 & 8.260 & 2.772 & 15.081 \\
C of V & 1.601 & 2.251 & 1.919 & 0.798 & 1.164 & 0.783 & 0.610 & 0.913 \\
\hline
\end{tabular}

Notes: Am is the Amihud's (2002) illiquidity ratio; SPR: is the quoted bid-ask spread; PSPR is the quoted proportional bid-ask spread; DEP: is the quoted quantity depth; DDEP: is the quoted dinar depth; QTY: is the quantity trading volume; NO: is the number of trades; VOL: is the dinar trading volume.

Table 3. Day-of-the week-effects

\begin{tabular}{|c|c|c|c|c|c|c|c|c|}
\hline Variable & $\mathrm{AM}$ & SPR & PSPR & DEP & DDEP & QTY & NO & VOL \\
\hline Sunday & 0.000 & 0.004 & $0.004^{*}$ & $385^{*}$ & 1809 & -168327 & -19 & -649918 \\
\hline Monday & 0.000 & $0.010^{*}$ & $0.005^{*}$ & 154 & 1107 & 155067 & $175^{*}$ & $1992283^{*}$ \\
\hline Tuesday & 0.000 & 0.002 & 0.002 & 186 & 817 & 72355 & 32 & 1124700 \\
\hline Wednesday & $0.000^{*}$ & 0.001 & 0.001 & 186 & 751 & 81940 & -56 & 1431990 \\
\hline Thursday & 0.000 & 0.002 & $0.004^{*}$ & 98 & 683 & 347814 & 47 & $2091959^{*}$ \\
\hline$L_{(-1)}$ & $0.137^{*}$ & $0.327^{*}$ & $0.379^{*}$ & $0.483^{*}$ & $0.453^{*}$ & $0.449^{*}$ & $0.638^{*}$ & $0.844^{*}$ \\
\hline$L_{(-2)}$ & $0.144^{*}$ & 0.045 & $0.084^{*}$ & $0.092^{*}$ & $0.042^{*}$ & $0.164^{*}$ & $0.131^{*}$ & $-0.150^{*}$ \\
\hline$L_{(-3)}$ & $0.124^{*}$ & $0.084^{*}$ & $0.089^{*}$ & $0.086^{*}$ & $0.104^{*}$ & $0.045^{*}$ & 0.049 & $0.123^{*}$ \\
\hline$L_{(-4)}$ & $0.105^{*}$ & $0.084^{*}$ & $0.065^{*}$ & 0.047 & $0.040^{*}$ & $0.077^{*}$ & 0.048 & $0.093^{*}$ \\
\hline$L_{(-5)}$ & $0.110^{*}$ & $0.068^{*}$ & $0.068^{*}$ & $0.071^{*}$ & 0.015 & $0.081^{*}$ & 0.041 & -0.006 \\
\hline$L_{(-6)}$ & $0.089^{*}$ & 0.043 & 0.027 & 0.044 & $0.056^{*}$ & $-0.060^{*}$ & -0.022 & 0.000 \\
\hline$L_{(-7)}$ & $0.056^{*}$ & $0.111^{*}$ & $0.075^{*}$ & 0.015 & 0.007 & $0.181^{*}$ & 0.047 & $0.085^{*}$ \\
\hline$L_{(-8)}$ & 0.025 & 0.053 & $0.066^{*}$ & 0.040 & -0.028 & 0.025 & $0.058^{*}$ & $-0.133^{*}$ \\
\hline$L \quad(-9)$ & $0.108^{*}$ & $0.083^{*}$ & 0.008 & 0.024 & $0.059^{*}$ & $0.045^{*}$ & -0.027 & $0.087^{*}$ \\
\hline \multirow[t]{2}{*}{$L \quad(-10)$} & $0.062^{*}$ & 0.035 & $0.061^{*}$ & $0.068^{*}$ & $0.139^{*}$ & -0.009 & 0.028 & 0.006 \\
\hline & \multicolumn{8}{|c|}{ Variance Equation } \\
\hline $\mathrm{C}$ & $0.000^{*}$ & 0.000 & 0.000 & $153316^{*}$ & $1.27 \times 10^{8 *}$ & $1.1 \times 10^{13^{*}}$ & $715^{*}$ & $1.3 \times 10^{13^{*}}$ \\
\hline $\operatorname{RESID}(-1)^{\wedge} 2$ & $0.238^{*}$ & $0.164^{*}$ & $0.146^{*}$ & $0.350^{*}$ & $0.994^{*}$ & $0.518^{*}$ & $0.029^{*}$ & $0.769^{*}$ \\
\hline GARCH(-1) & 0.842 & 0.872 & 0.882 & $0.745^{*}$ & -0.010 & 0.079 & $0.973^{*}$ & -0.061 \\
\hline $\mathrm{R}^{\wedge} 2$ & 0.297 & 0.293 & 0.384 & 0.644 & 0.467 & 0.853 & 0.904 & 0.781 \\
\hline Adjusted $\mathrm{R}^{\wedge} 2$ & 0.291 & 0.288 & 0.379 & 0.641 & 0.463 & 0.852 & 0.903 & 0.779 \\
\hline
\end{tabular}

Notes: Daily aggregate market liquidity is regressed using GARCH $(1,1)$ model on five dummy variables, one for each day of the week. The aggregate market liquidity is measured by a different proxy each time regression is run. $L$ is the aggregate market liquidity. Am is the Amihud's (2002) illiquidity ratio; SPR: is the quoted bid-ask spread; PSPR is the quoted proportional bid-ask spread; DEP: is the quoted quantity depth; DDEP: is the quoted dinar depth; QTY: is the quantity trading volume; NO: is the number of trades; VOL: is the dinar trading volume. Ten days lags of the dependent variable are added as additional regressors in an attempt to correct for the autocorrelation between residuals. * denotes statistical significance at $5 \%$ level. 
Table 4. Macroeconomic sources of liquidity (OLS)

\begin{tabular}{lcccccccc}
\hline Variable & CAM & CSPR & CPSPR & CDEP & CDDEP & CQTY & CNO & CVOL \\
\hline C & $-0.678^{*}$ & 600 & 0.974 & -0.389 & $-0.619^{*}$ & -0.424 & $-0.349^{*}$ & $-0.645^{*}$ \\
CGDP & 1.840 & 296 & -0.381 & -0.608 & -0.960 & $-2.165^{*}$ & $-1.429^{*}$ & $-3.126^{*}$ \\
CM2 & $13.234^{*}$ & -32186 & -80.362 & -1.930 & -1.460 & -2.445 & -1.572 & 0.831 \\
CCPI & 2.980 & 10756 & 31.839 & -0.021 & $9.538^{*}$ & -1.909 & 0.563 & $4.650^{*}$ \\
CIP & $-4.761^{*}$ & 2875 & 3.721 & -0.071 & 2.071 & $2.433^{*}$ & $1.973^{*}$ & $3.590^{*}$ \\
CTERM & 0.122 & -1088 & -2.970 & -0.066 & 0.118 & 0.053 & 0.060 & $0.298^{*}$ \\
CCREDIT & 0.196 & -1099 & -2.699 & 0.071 & 0.229 & -0.173 & -0.064 & -0.022 \\
CUNEMP & $2.936^{*}$ & 18.184 & 5.884 & 0.722 & 0.868 & $-0.934^{*}$ & -0.463 & $-0.754^{*}$ \\
MKT & $-111^{*}$ & -136410 & -463 & $79^{*}$ & $77^{*}$ & $82^{*}$ & $60^{*}$ & $118^{*}$ \\
VOT & 286 & 678944 & 2406 & $601^{*}$ & $620^{*}$ & $739^{*}$ & $489^{*}$ & $735^{*}$ \\
$\mathrm{R}^{\wedge} 2$ & 0.563 & 0.588 & 0.566 & 0.489 & 0.689 & 0.636 & 0.797 & 0.847 \\
Adjusted R^2 & 0.367 & 0.403 & 0.370 & 0.259 & 0.549 & 0.472 & 0.706 & 0.778 \\
\hline
\end{tabular}

Notes: Percentage change in aggregate market liquidity is regressed in a quarterly basis on the percentage change in each of the following macroeconomic variables: GDP is the Gross Domestic Product; M2 is the Money Supply (2); IP is the Industrial Production, CPI is the Consumer Price Index, UNEMP is the Unemployment rate; TERM is the term spread; CREDIT is the quality spread. "C" preceding each acronym denotes the percentage change from quarter $t-1$ to quarter $t$. Percentage changes are used to avoid nonstationarity problem. Market return (MKT) and volatility (VOT) are added as additional regressors in order to control their effect on the dependent variable. The aggregate market liquidity is measured by a different proxy each time regression is run. Am is the Amihud's (2002) illiquidity ratio; SPR is the quoted bid-ask spread; PSPR is the quoted proportional bid-ask spread; DEP is the quoted quantity depth; DDEP is the quoted dinar depth; QTY is the quantity trading volume; NO is the number of trades; VOL is the dinar trading volume. OLS is used as an estimator with Newey-West HAC Standard Errors \& Covariance to account for serial correlation and heteroskedasticity.* denotes statistical significance at $5 \%$ level.

Table 5. Chow Break Point Test

\begin{tabular}{ccccccccc}
\hline Chow test & CAM & CSPR & CPSPR & CDEP & CDDEP & CQTY & CNO & CVOL \\
\hline F-statistic & 1.015 & 0.360 & 0.671 & 0.416 & 1.364 & 1.210 & $3.254^{*}$ & 1.189 \\
Probability & 0.491 & 0.939 & 0.730 & 0.909 & 0.316 & 0.384 & 0.038 & 0.395 \\
\hline
\end{tabular}

Notes: Chow Break Point Test assumes a null hypothesis of no structural changes in data. 2006 is selected as a break point.

Table 6. Macroeconomic sources of liquidity (VAR)

\begin{tabular}{ccccccccc}
\hline Variable & CAM & CSPR & CPSPR & CDEP & CDDEP & CQTY & CNO & CVOL \\
\hline CL(-1) & 0.334 & 0.620 & 0.492 & $-1.031^{*}$ & -0.713 & 0.288 & 1.087 & 0.452 \\
CL(-2) & -0.163 & -0.806 & -1.560 & 0.236 & 0.137 & $-0.661^{*}$ & -0.364 & -1.076 \\
CGDP(-1) & 3.250 & 15715.500 & 12.792 & $-5.383^{*}$ & -4.381 & -3.161 & -1.341 & -4.784 \\
CGDP(-2) & 0.368 & -14207.320 & -65.469 & 0.074 & -0.013 & 0.645 & 0.733 & -1.647 \\
CM2(-1) & -7.002 & 34117.500 & 203.721 & -1.323 & 6.418 & $8.377^{*}$ & 5.124 & $12.496^{*}$ \\
CM2(-2) & 5.214 & -14724.670 & 20.805 & $-13.759^{*}$ & -4.212 & -7.223 & -7.355 & -4.389 \\
CCPI(-1) & 4.171 & 61347.520 & $193.958^{*}$ & 2.971 & 2.071 & -10.514 & -6.277 & $-18.935^{*}$ \\
CCPI(-2) & 6.749 & $-61068.760^{*}$ & -107.802 & -2.516 & -6.745 & -3.524 & 0.875 & 7.785 \\
CIP(-1) & 3.832 & -12755.900 & -28.298 & $3.378^{*}$ & 2.485 & 0.472 & -3.568 & -0.879 \\
CIP(-2) & -2.475 & -4106.585 & 2.226 & 4.087 & 1.817 & 3.183 & 2.463 & $7.977^{*}$ \\
CTERM(-1) & -0.363 & 2111.983 & 8.877 & -0.091 & 0.196 & -0.317 & -0.111 & -0.333 \\
CTERM(-2) & 0.556 & -1508.304 & -3.199 & -0.222 & 0.180 & $0.469^{*}$ & 0.020 & $0.869^{*}$ \\
CCREDIT(-1) & -0.547 & 2670.100 & 0.328 & 0.133 & -0.156 & -0.103 & -0.035 & -0.372 \\
CCREDIT(-2) & 0.309 & -2698.496 & -9.000 & 0.074 & 0.096 & -0.003 & 0.175 & $0.468^{*}$ \\
MKT(-1) & -68.313 & -525548.200 & -2236.831 & 49.596 & 78.575 & 14.772 & -32.713 & 74.358 \\
MKT(-2) & $-152.114^{*}$ & 13329.950 & -1086.149 & 14.533 & 60.745 & 96.381 & 98.418 & 202.095 \\
VOT(-1) & -697.400 & -464121.500 & 4947.244 & $952.872^{*}$ & $1026.255^{*}$ & 578.270 & 257.958 & $1156.690^{*}$ \\
VOT (-2) & 732.408 & 3145549.000 & $10788.700^{*}$ & $-948.236^{*}$ & $-933.445^{*}$ & -185.264 & -419.980 & -494.819 \\
CUNEMP(-1) & $-4.506^{*}$ & -8513.323 & -22.984 & -1.109 & -0.920 & 0.080 & 1.787 & 1.990 \\
CUNEMP(-2) & -0.326 & -3750.816 & 1.972 & $-3.244^{*}$ & $-2.504^{*}$ & $-3.040^{*}$ & -0.207 & -2.511 \\
C & -0.270 & -3359.140 & -20.253 & $0.889^{*}$ & 0.183 & 0.072 & 0.369 & -0.346 \\
R-squared & 0.913 & 0.782 & 0.841 & 0.946 & 0.907 & 0.944 & 0.856 & 0.924 \\
Adj. R-squared & 0.563 & -0.092 & 0.206 & 0.732 & 0.534 & 0.719 & 0.281 & 0.620 \\
\hline VAR is & & & & & & & &
\end{tabular}

Notes: VAR is estimated for the same variables in Table 4. All variables are set as endogenous except the intercept. A lag structure of 2 is selected according to AIC. 


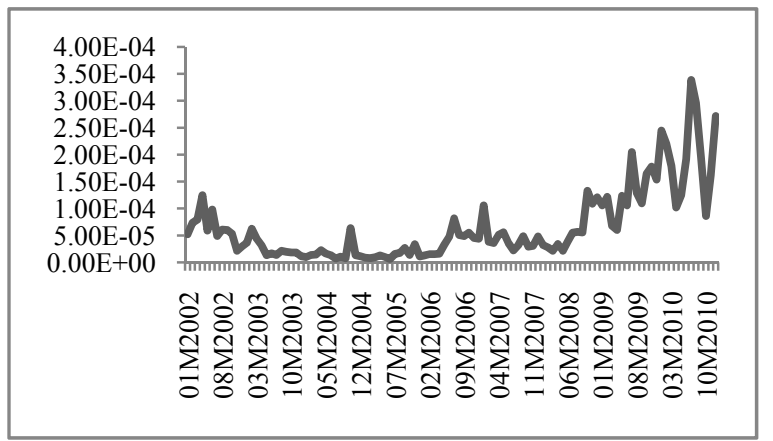

Figure 1. Illiquidity Ratio

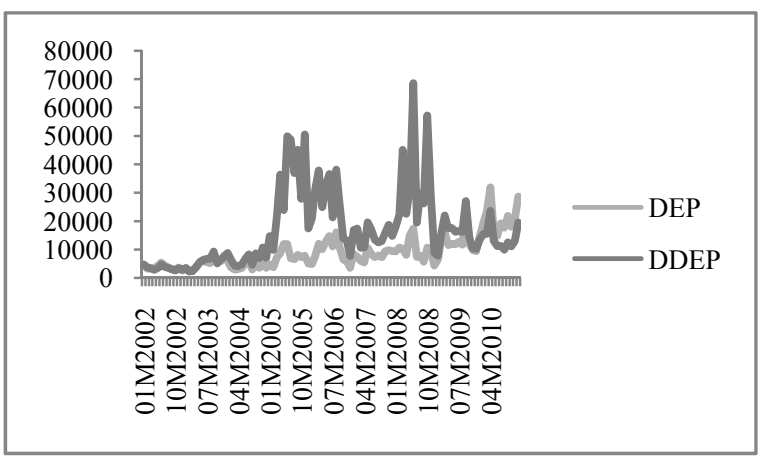

Figure 3. Depth Measures

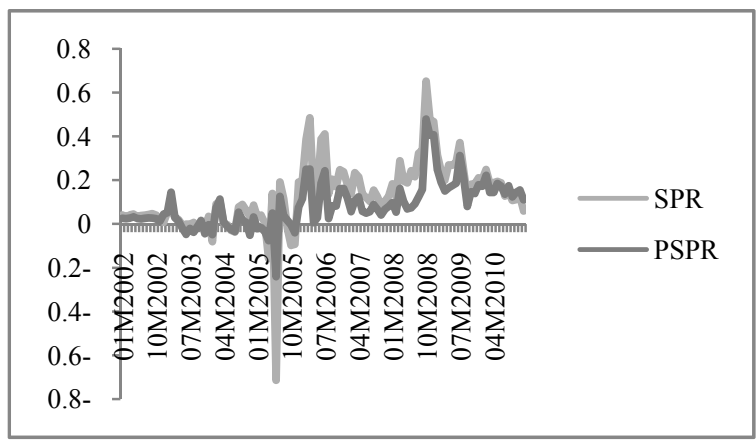

Figure 2. Spread Measures

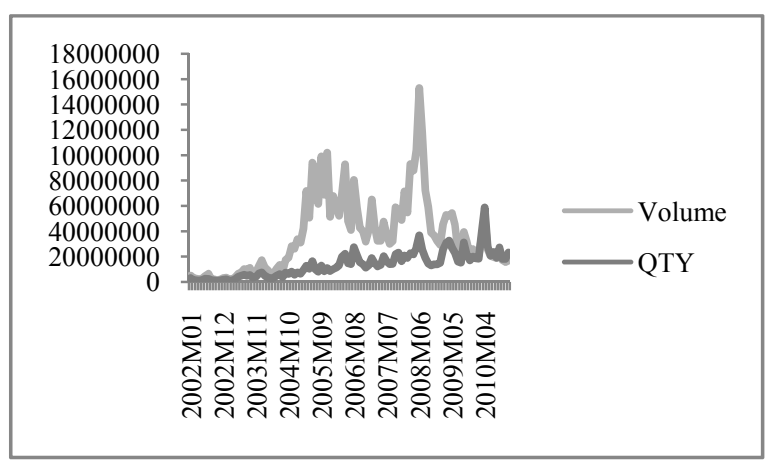

Figure 4. Trading Activity Measures

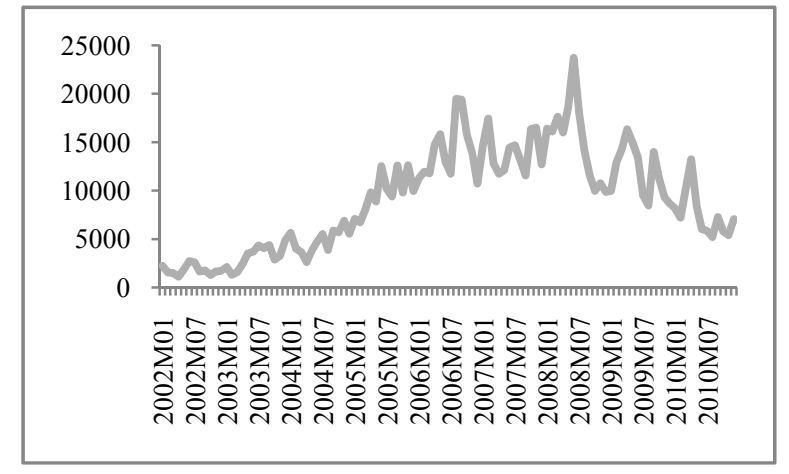

Figure 5. Number of Trades 